\title{
SOMATIC AND TYPOLOGICAL DIFFERENTIATION OF FIRSTYYEAR MALE AND FEMALE STUDENTS FROM THE JOZEF PILSUDSKI UNIVERSITY OF PHYSICAL EDUCATION IN WARSAW
}

\author{
Karol Gryko, 1, A, C, D Anna Kopiczko, 2, B, D Krzysztof Krawczyk,, , , D \\ Iwona Maliszewska, ${ }^{1, B, D}$ Krzysztof Perkowski ${ }^{1, A}$ \\ 1 Jozef Pilsudski University of Physical Education, Department of Athletics and Sports Games, Chair of Sport, Poland \\ 2 Jozef Pilsudski University of Physical Education, Department of Anthropology and Health Promotion, Chair of Biomedical Sciences, Poland \\ ${ }^{3}$ Maria Curie-Sklodowska University, Center of Physical Culture, Poland

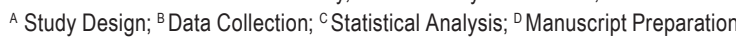

\author{
Address for correspondence: \\ Karol Gryko \\ Jozef Pilsudski University of Physical Education in Warsaw, Department of Physical Education, Chair of Sport, \\ Department of Athletics and Sports Games \\ Marymoncka 34, 00-968 Warsaw, Poland \\ E-mail:k.gryko@awf.edu.pl
}

\begin{abstract}
Ahstract University education is a period of human life when lifestyles or person's activity are critical to the development of somatic build, while identification of the somatotype allows for corrections or recommendation of effective physical activity programmes. The main aim of this study was to assess selected features of body build and to identify somatotypes of young people at early stages of education at Jozef Pilsudski University of Physical Education in Warsaw depending on the field of study. The study examined 394 students of physical education (PE) and sport (S). Anthropometric measurements were the main research method used in the study. Physical body build (somatotype) was identified using the Heath-Carter method. The ANOVA/ MANOVA analysis of variance was employed to determine the significance of differences in values of anthropometric and somatic characteristics between the groups of students.

Students of physical education were characterized by a somatotype with a code of 3.08-4.6-2.62 (endomorphic mesomorph). In students of sport, the somatotype code was 3.0-4.58-2.37 (endomorphic mesomorph). Compared to $S$ students, significantly $(p<0.05)$ higher values (by 10.5\%) of the ectomorphy component were found in PE students.

The results revealed the need for more research into the somatic build of students of physical education, taking into account the changes in their living conditions (including socio-economic environment), since graduates are expected to promote physical activity in the future. It is also necessary to carry out identical research at the end of studies in order to evaluate the effect of university curricula on the somatic build of students.
\end{abstract}

Key words anthropometry, endomorphy, mesomorphy, ectomorphy, students 


\section{Introduction}

Observation of changes caused by the onset of modern civilization and intergenerational changes provide researchers with a great deal of valuable information on the health status of successive generations. Research on university students has been carried out all around the world (Ekblom, Engström, Ekblom, 2007; Yildiz, Karakaş, Güneş, Köse, 2009) and in Poland for many years. It contributes to a better understanding of the determinants of the health status of a young generation (Milicer, Skibińska, Skład, 1974; Mleczko, Januszewski, 2009; Pasiut, 2012; Saczuk, Wasiluk, Wilczewski, Wilczewski, 2016; Stachoń, Burdukiewicz, Pietraszewska, Andrzejewska, 2012). Universities (particularly those which offer PE courses) are important institutions that promote active lifestyles in society. It is students of pedagogical and biomedical courses who, after graduation, will promote physical activity among both children and adults.

Research indicates that the specificity of particular university studies and courses affects students' lifestyles and health status (Maaroos, Landor, 2001; Pasiut, 2012). Studying at university is a time of dynamic changes related to a circadian rhythm which is different compared to earlier stages of education, attempting to combine work and study, and participating in university life. It is often stressed that during this period of life, students may be exposed to irregular lifestyles and addictions (Huang et al., 2003; Maaroos, Landor, 2001), whereas the prevalence of overweight and obesity is high (Phaswana, Ramalivhana, Amusa, 2015; Truter, Pienaar, DuToit, 2010). Studies on the somatic build of students from different universities and courses have emphasized differences mainly in height and weight indices and body composition. Despite similar age and, in most of the students, living in big cities while studying, differences in musculature and body fat are considerable. They depend on the type of classes attended at university. Body size, proportions and body composition are crucial to physical fitness and are the subject of scientific research (Brničević, Duplančić, Jukić, 2014; Kaźmierczak, Bolesławska, Główka, Dzięcioł, Przysławski, 2012; Nikbakht, 2011; Peterson, Koskel, 2006; Raschka, Aichele, 2014; Tzarova, 2013; Vedat, 2013). Somatotype, which represents the description of body build of an individual, is defined by one of the three types: endomorph, characterized as rounded body shape; mesomorph, with muscular body; and ectomorph, characterized as slim body build (Carter, 2002). Physical activity is an important causative factor in achieving the desired positive levels of physical health by students. It points to the need for promoting and enabling university students to participate in various forms of physical culture (Mirek, Mleczko, 2005).

University education is a period of human life when lifestyles or person's activity are critical to the development of somatic build, while identification of the somatotype allows for corrections or recommendation of effective physical activity programmes (Cynarski, Obodyński, Litwiniuk, 2005). The university curricula for students of physical education and sports are characterized by a significantly higher number of practical activities with highintensity exercises. This can lead to the differences in body build compared to students from other university majors. Knowledge in this field facilitates to determine the body profiles of future students as well as students who have to participate in many practical activities in accordance with the study programme.

The main aim of the study was to assess selected characteristics of body build and to determine somatotypes of young people starting education at Jozef Pilsudski University of Physical Education in Warsaw in the field of physical education and sport. Furthermore, the research results were related to findings of similar studies in Poland and other countries. 


\section{Material and methods}

The study examined 394 first-year students of physical education $(n=316)$ and sport $(n=78)$ from Jozef Pilsudski University of Physical Education in Warsaw. The students from each group were divided according to gender (female students: $n=85$ and $n=20$, respectively; male students: $n=231$ and $n=58$, respectively). General characteristics of students with regard to the field of study and gender are presented in Table 1.

Table 1. Baseline characteristics of the study participants

\begin{tabular}{|c|c|c|c|c|}
\hline & Variable & Mean $\pm S D$ & Median & Range \\
\hline \multicolumn{5}{|l|}{ Course } \\
\hline & age & $20.4 \pm 5.2$ & 19.8 & $17.2-27.0$ \\
\hline \multirow[t]{3}{*}{$P E(n=316)$} & body mass & $72.9 \pm 10.9$ & 72.8 & $45.8-130.6$ \\
\hline & body height & $177.3 \pm 8.5$ & 177.6 & $152.5-197.5$ \\
\hline & age & $19.7 \pm 0.9$ & 19.4 & $17.5-22.4$ \\
\hline \multirow[t]{3}{*}{$S(n=78)$} & body mass & $75.4 \pm 10.4$ & 75.4 & $52.9-98.0$ \\
\hline & body height & $178.2 \pm 8.6$ & 178.7 & $161.0-196.3$ \\
\hline & age & $20.2 \pm 4.6$ & 19.7 & $17.2-27.0$ \\
\hline \multirow[t]{2}{*}{ Total $(n=394)$} & body mass & $73.5 \pm 10.9$ & 73.6 & $45.8-130.6$ \\
\hline & body height & $177.5 \pm 8.5$ & 177.8 & $152.5-197.5$ \\
\hline \multicolumn{5}{|l|}{ Gender } \\
\hline & age & $19.9 \pm 1.2$ & 19.6 & $18.8-27.0$ \\
\hline \multirow[t]{3}{*}{ Females PE $(n=85)$} & body mass & $63.6 \pm 9.3$ & 62.9 & $45.8-88.9$ \\
\hline & body height & $167.8 \pm 5.3$ & 167.7 & $152.5-181.6$ \\
\hline & age & $19.9 \pm 1.0$ & 19.7 & $18.8-22.3$ \\
\hline \multirow[t]{3}{*}{ Females $S(n=20)$} & body mass & $64.6 \pm 7.2$ & 65.7 & $52.9-75.7$ \\
\hline & body height & $168.7 \pm 6.2$ & 167.2 & $161.0-184.4$ \\
\hline & age & $19.9 \pm 1.2$ & 19.6 & $18.8-27.0$ \\
\hline \multirow[t]{3}{*}{ Total $(n=105)$} & body mass & $63.8 \pm 8.9$ & 63.1 & $45.8-88.9$ \\
\hline & body height & $167.9 \pm 5.5$ & 167.5 & $152.5-184.4$ \\
\hline & age & $20.6 \pm 6.0$ & 19.8 & $17.2-24.9$ \\
\hline \multirow[t]{3}{*}{ Males PE $(n=231)$} & body mass & $76.4 \pm 9.4$ & 75.5 & $54.8-130.6$ \\
\hline & body height & $180.8 \pm 6.5$ & 180.9 & $161.2-197.5$ \\
\hline & age & $19.6 \pm 0.9$ & 19.3 & $17.5-22.4$ \\
\hline \multirow[t]{3}{*}{ Males $S(n=58)$} & body mass & $79.2 \pm 8.5$ & 79.1 & $61.4-98.0$ \\
\hline & body height & $181.5 \pm 6.6$ & 180.9 & $163.7-196.3$ \\
\hline & age & $20.4 \pm 5.4$ & 19.8 & $17.2-24.9$ \\
\hline \multirow[t]{2}{*}{ Total $(\mathrm{n}=289)$} & body mass & $77.0 \pm 9.3$ & 76.0 & $54.8-130.6$ \\
\hline & body height & $181.0 \pm 6.5$ & 180.9 & $161.2-197.5$ \\
\hline
\end{tabular}

$\mathrm{n}$ - number of study participants. Age is presented in years, body height in $\mathrm{cm}$, and body mass in $\mathrm{kg}$.

The procedure was approved by the Ethics Committee for Scientific Research of the University of Physical Education in Warsaw. Examinations were carried out by the team of experts trained in measurement techniques between October and December 2015 at the University of Physical Education in Warsaw. Before the examinations, all the participants were informed about the research project, its aim, benefits and procedures, and about a possibility of withdrawal from participation in the research without giving reasons at any time. The study inclusion criterion was 
a written informed consent provided by the participant. Anthropometry was the main research method used in the study. Body measurements were taken with participants wearing their underwear only (without outer garments) in accordance with general standards (Charzewska, Kopiczko, Bieńko, Pastuszak, 2017). The position of the body was in line with the recommendations of the International Biological Programme (Weiner, Lourie, 1969). The following variables were recorded: age (years), body mass $(\mathrm{kg})$, body height $(\mathrm{cm})$, skinfolds (triceps, subscapular, supraspinal, calf), girths (flexed arm, calf), and humerus and femur breadth. The measurements were made using anthropometric tools such as an anthropometer with a measuring range of $2.10 \mathrm{~m}$ (accuracy: $1 \mathrm{~mm}$ ), a small calliper (accuracy: $1 \mathrm{~mm}$ ), a tape measure (accuracy: $1 \mathrm{~mm}$ ) and the Harpenden Skinfold Caliper (accuracy: $0.2 \mathrm{~mm}$ ). Skinfolds were measured in all participants by one researcher three times (mean result was taken into account). The Heath-Carter method (Carter, Heath, 1990) and Somatotype 1.2.6 software (MER Goulding Software Development, Australia) were used to identify somatotypes. The Shapiro-Wilk test was employed to verify the distribution of results. The data were converted into numerical values using the following indices: arithmetic means $(X)$, standard deviations (SD), maximum and minimum values (Min-Max) and medians (Me). The ANOVA/MANOVA analysis of variance (post hoc Tukey tests, with statistical significance set at $p<0.05$ ) was employed to evaluate the significance of differences in values of anthropometric and somatic features between the groups of students. All the calculations and analyses were made using STATISTICA software (v.12, Stat. Soft. USA).

\section{Results}

Research results were shown in tables and figures (with regard to somatotypes). Descriptive statistics of all the measurements are presented in Table 2, while individual somatotypes of students together with the mean profile (circle) are illustrated in Figure 2.

Tahle 2. Descriptive statistics of the measured anthropometric variables

\begin{tabular}{lcccccccc}
\hline \multirow{2}{*}{ Variables } & \multicolumn{2}{c}{ Females $\mathrm{PE}(\mathrm{n}=85)$} & \multicolumn{2}{c}{ Females $\mathrm{S}(\mathrm{n}=20)$} & \multicolumn{2}{c}{ Males $\mathrm{PE}(\mathrm{n}=231)$} & \multicolumn{2}{c}{ Males $\mathrm{S}(\mathrm{n}=58)$} \\
\cline { 2 - 8 } & $\mathrm{M} \pm \mathrm{SD}$ & range & $\mathrm{M} \pm \mathrm{SD}$ & range & $\mathrm{M} \pm \mathrm{SD}$ & range & $\mathrm{M} \pm \mathrm{SD}$ & range \\
\hline Triceps SF & $14.3 \pm 5.2$ & $6.0-35.5$ & $14.5 \pm 4.8$ & $6.9-23.7$ & $9.2 \pm 4.2$ & $3.2-30.0$ & $8.5 \pm 2.6$ & $3.6-15.1$ \\
Subscapular SF & $13.7 \pm 5.3$ & $5.4-34.5$ & $12.9 \pm 3.9$ & $7.5-21.4$ & $10.6 \pm 3.4$ & $5.0-26.5$ & $10.4 \pm 2.6$ & $6.5-18.3$ \\
Supraspinal SF & $12.5 \pm 5.4$ & $5.0-35.0$ & $12.8 \pm 3.5$ & $7.2-19.8$ & $9.2 \pm 4.6$ & $4.0-31.3$ & $9.1 \pm 3.4$ & $3.7-18.8$ \\
Calf SF & $13.4 \pm 6.5$ & $4.0-41.5$ & $14.6 \pm 5.7$ & $4.5-24.1$ & $9.2 \pm 4.5$ & $3.0-28.5$ & $8.7 \pm 3.0$ & $4.5-16.0$ \\
Flexed arm G & $28.6 \pm 2.7$ & $23.0-38.0$ & $29.0 \pm 2.4$ & $25.4-33.5$ & $33.5 \pm 2.9$ & $26.5-45.5$ & $33.8 \pm 30$ & $29.0-40.5$ \\
Calf G & $36.3 \pm 4.0$ & $25.0-62.0$ & $36.7 \pm 2.2$ & $32.0-42.0$ & $37.5 \pm 2.6$ & $26.5-46.5$ & $37.8 \pm 2.0$ & $32.1-41.9$ \\
Humerus B & $6.3 \pm 0.5$ & $5.2-8.2$ & $6.3 \pm 0.4$ & $5.2-7.0$ & $7.2 \pm 0.5$ & $5.8-9.2$ & $7.1 \pm 0.5$ & $5.7-8.5$ \\
Femur B & $9.0 \pm 0.6$ & $7.5-11.5$ & $9.0 \pm 0.5$ & $8.4-9.9$ & $9.6 \pm 0.6$ & $8.0-11.4$ & $9.6 \pm 0.6$ & $8.3-10.8$ \\
HWR & $42.2 \pm 1.7$ & $37.9-45.3$ & $42.1 \pm 1.7$ & $39.2-45.8$ & $42.7 \pm 1.6$ & $37.5-46.8$ & $42.3 \pm 1.2$ & $40.1-46.1$ \\
BMI & $22.5 \pm 2.8$ & $18.0-30.4$ & $22.7 \pm 2.4$ & $18.3-27.1$ & $23.3 \pm 2.5$ & $17.9-34.5$ & $24.0 \pm 1.8$ & $18.9-28.0$ \\
\% Fat & $26.2 \pm 3.3$ & $20.7-35.7$ & $26.4 \pm 2.9$ & $21.2-31.7$ & $16.6 \pm 3.4$ & $9.7-41.5$ & $17.1 \pm 2.3$ & $10.8-22.0$ \\
Endomorphy & $4.08 \pm 1.3$ & $1.7-7.9$ & $4.09 \pm 1.0$ & $2.5-5.6$ & $2.71 \pm 1.0$ & $1.2-6.9$ & $2.62 \pm 0.7$ & $1.3-4.3$ \\
Mesomorphy & $4.03 \pm 1.4$ & $1.6-8.7$ & $4.12 \pm 1.1$ & $1.5-6.1$ & $4.81 \pm 1.3$ & $1.6-9.0$ & $4.74 \pm 1.2$ & $2.3-7.3$ \\
Ectomorphy & $2.36 \pm 1.1$ & $0.1-4.6$ & $2.26 \pm 1.3$ & $0.2-5.0$ & $2.72 \pm 1.0$ & $0.1-5.7$ & $2.40 \pm 0.9$ & $0.9-5.1$ \\
\hline
\end{tabular}

M - mean, SF - skinfold, G - girth, B - breadth, HWR - height-weight ratio. 
The analysis of values in terms of somatic build of students from Jozef Pilsudski University of Physical Education in Warsaw (Figure 1) depending on the field of study revealed that both physical education (PE) students and sport (S) students had endo-mesomorphic body build (3.08-4.6-2.62 and 3.0-4.58-2.37, respectively; the values represent endomorphy, mesomorphy and ectomorphy components). Compared to S students, significantly $(p<0.05)$ higher values (by 10.5\%) of the ectomorphy component were found in PE students (Figure 1).

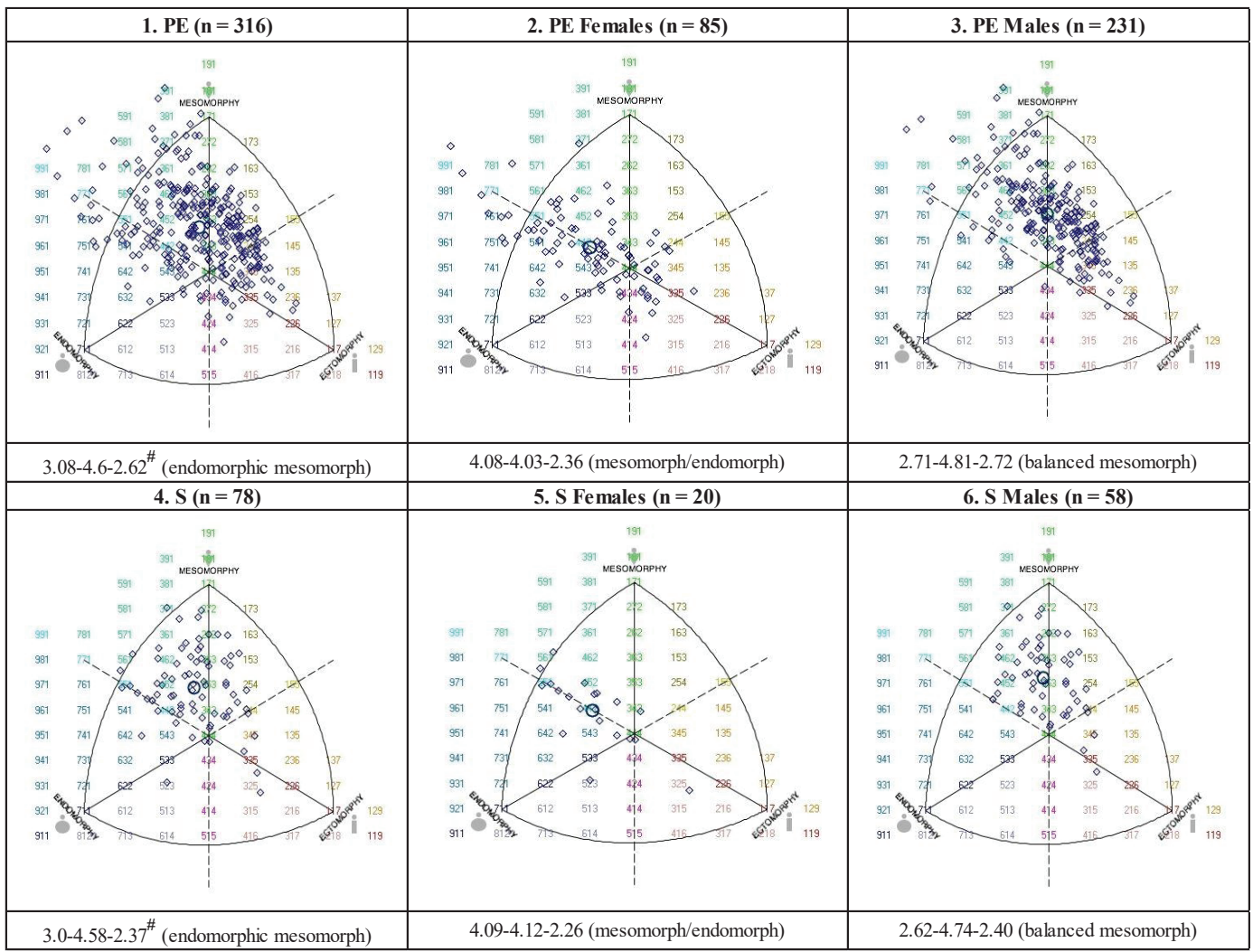

Significant differences between PE and S students (ectomorphic): $\# p<0.05$; the squares are individual somatotypes, and the circle is the mean profile.

Figure 1. Somatocharts of study participants according to a study course and gender

The anthropometric measurements were used to identify the somatotypes of all first-year students. Mean somatotype was defined by code 3.06-4.59-2.57 (Figure 2), which corresponds to the endo-mesomorphic type. Female PE students had meso-endomorphic somatotype (4.08-4.03-2.36). The same type was observed in female S students. 


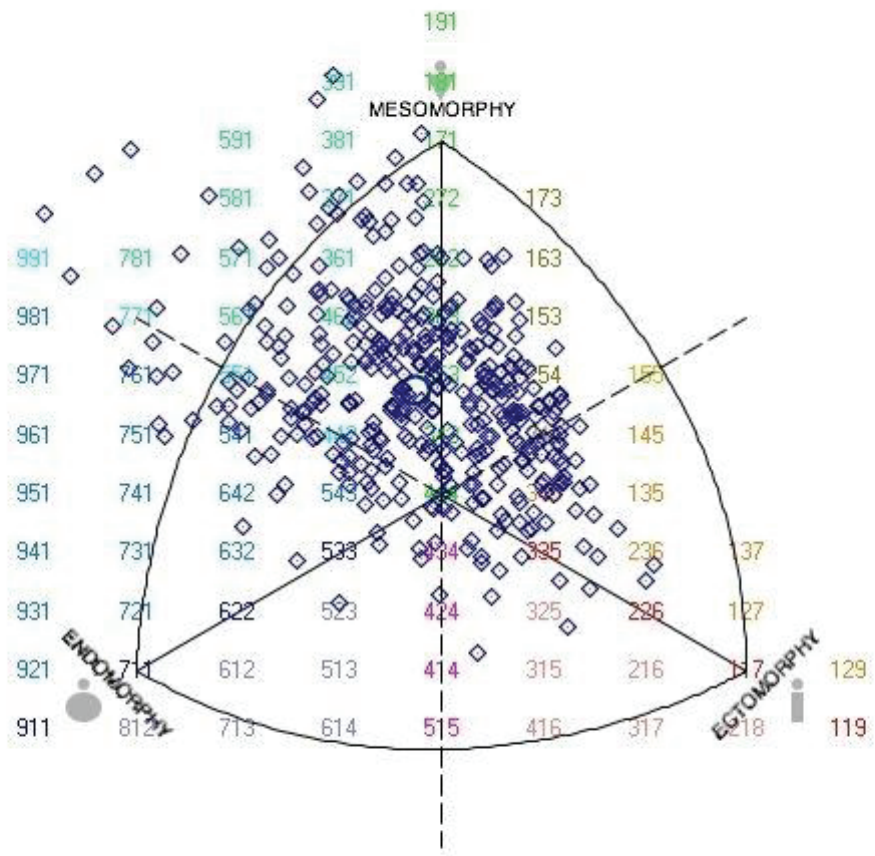

The squares are individual somatotypes, and the circle is the mean profile.

Figure 2. Somatotype distribution for students from the University of Physical Education in Warsaw

In the case of male participants, both PE and S students had balanced mesomorphic body build (2.71-4.812.72) (Figure 1). No significant differences were revealed in values of other variables (body fat percentage, BMI and anthropometric features) depending on the university course.

\section{Disculusion}

Body build and somatotype represent one of the basic biometric human features. In the context of physical activity and performance in different sports (as is the case with university students of sport-related courses), body build is extremely important in terms of movement efficiency and technique. Some studies conducted in various countries (Maaroos, Landor, 2001; Nikbakht, 2011) and in Poland have focused on determining characteristics of body build and somatotypes (often in relation to health status) typical of university students of sport-related courses (Mleczko, Januszewski, 2009; Pasiut, 2012). The present study of students from Jozef Pilsudski University of Physical Education in Warsaw revealed that the most common somatotype was 3.08-4.6-2.62. In this somatotype, the mesomorph component prevailed, endomorphy was on an average level, and there was a small component of ectomorphy, i.e. body build was muscular rather than round, slim or fragile. This type is often characterized as really plastic and responding well to physical exercise (both strength and endurance exercise). The smallest ectomorphy component may be due to the fact that during studying, students are involved more in general training than that focused on aesthetics and technique, with slender body build found in selected athletes. A review of studies 
on university students of sport (Table 3) demonstrated correlations similar to those obtained in the present study. Somatic characteristics are determined by the field of study.

Table 3. Somatotypes of students noted in other studies

\begin{tabular}{|c|c|c|c|c|c|}
\hline Study & Group & $\mathrm{n}$ & Endo & Meso & Ecto \\
\hline \multirow{2}{*}{ N. Saritas et al. (2010) } & Erciyes University, Turkey, males & 61 & 4.03 & 4.44 & 2.98 \\
\hline & Erciyes University, Turkey, males & 137 & 2.84 & 5.25 & 2.68 \\
\hline M. Nikbakht (2011) & Tehran University, Iran, males & 45 & 6.95 & 3.01 & 2.28 \\
\hline R. Tzarova (2013) & Technical University, Sofia, Bulgaria & 49 & 0.2 & 3.3 & 3.0 \\
\hline M.M. Brničević et al. (2014) & University of Split, females & 115 & 4.56 & 3.55 & 2.86 \\
\hline \multirow{2}{*}{ A. Khasawneh (2015) } & PE students, females, Jordan & 27 & 6.0 & 2.7 & 1.8 \\
\hline & PE students, males, Jordan & 44 & 4.3 & 2.6 & 2.8 \\
\hline M. Phaswana et al. (2015) & University of Venda, RSA, females and males & 118 & 3.94 & 4.52 & 1.72 \\
\hline S. Saha (2015) & PE students in India & 250 & 2.86 & 4.67 & 3.85 \\
\hline
\end{tabular}

The study on PE students from Sports College of Erciyes University (Saritas, Özkarafaki, Pepe, Büyükipekçi, Çoksevim, 2010) revealed significantly greater mesomorphy among young female and male students of sportrelated courses compared to those from other faculties; however, the percentage of the ectomorph component was similar. National studies focused on the assessment of the biological state of male and female PE students compared to students of other faculties from the biggest state universities in Krakow (Pasiut, 2012). It was noted that PE students had significantly lower levels of body fat, which may result in a lower risk of cardiovascular diseases, obesity, diabetes or osteoporosis at a later age. Energy expenditure due to physical activity in young women significantly determines body mass and body fat, which highlights the role of physical activity in reducing obesity and its health consequences (Ekelund et al., 2005; Tjønna et al., 2008). Less active women are characterized by the highest levels of body fat and the lowest levels of lean body mass. The most active women are the most muscular and display the lowest levels of body fat (Hickner et al., 2001; Stachoń, Pietraszewska, Burdukiewicz, Andrzejewska, 2013). The findings of the study conducted by A. Stachon et al. (2013) on female students from the University of Physical Education in Wroclaw indicated that body fat percentage depends on the intensity of physical activity. Students who declared high-intensity physical activity had lower values of body fat percentage than their peers who performed moderate- and low-intensity physical activity (Stachon et al., 2013). Mean value of body fat percentage in female students who participated in the present study was $20.3 \%$, whereas this value in their peers from Rzeszow was 22.6\% (Barabasz, Zadarko, 2010).

In the case of female students from the University of Physical Education in Warsaw declaring low and high levels of energy expenditure, mean values of body fat percentage were $24.7 \%$ and $23.2 \%$, respectively (Czajkowska, Mazurek, Lutosławska, Żmijewski, 2010). Correlations between total body fat and subcutaneous fat were investigated by P.J. Teixeira et al. (Teixeira, Sardinha, Going, Lohman, 2001). Studies conducted by other researchers also revealed that women who declared high levels of physical activity (at least four times a week, one hour each time) displayed lower levels of subcutaneous fat. They also had a significantly lower thickness of subscapular, triceps, supraspinal, calf and abdominal skinfolds (Alizadeh et al., 2013; Kromhout, Bloemberg, Seidell, Nissinen, Menotti, 2001; Stachoń et al., 2013). These studies also confirmed women's tendency to reduce skinfolds together with an 
increase in physical activity. There are examples in the literature of results of body skinfolds measurements highly correlated with the results of total body fat measurements (expressed in percentage values) (Teixeira et al., 2001).

The findings of the study carried out by U. Pasiut (2012) on a large random sample seem to confirm correlations between body build and functional indices of PE students showing their better physical performance. This appears to result from selection and lifestyle-related differences, particularly in the levels of physical activity connected with their university and sports university curricula.

Various studies have demonstrated a common tendency for more healthy body build and body composition found among students of sports universities and universities associated with broadly understood physical activity. Difficulties in performing comparative analyses of studies on somatic build may stem from applying different measurement methods (anthropometric measurement vs. analysis using body composition analysers) and different body build typologies (Heath-Carter and Wanke or Kretschmer). Such difficulties result mainly from measurement inaccuracy.

In the case of the present study, further research is needed due to some limitations. No analysis was carried out regarding factors such as motor abilities or information about previous physical activity (performed before university education) that may have involved sports training.

Different body build types can be observed in strength, endurance, technical or aesthetic sports. Students attending sports-related courses constitute a selected group as the majority of them have been physically active before. A multi-disciplinary analysis performed on a more heterogeneous sample within a longitudinal study would provide a full picture of the examined issues.

\section{Conclusions}

First-year students of the Jozef Pilsudski University of Physical Education in Warsaw from both PE and $S$ groups were characterized by endo-mesomorphic somatotype. S students had significantly lower values of the ectomorphy component compared to PE students. The results revealed the need for more research into the somatic build of students of physical education, taking into account the changes in their living conditions (including socioeconomic environment), since graduates are expected to promote physical activity in the future. It is also necessary to carry out identical research at the end of studies in order to evaluate the effect of university curricula on the somatic build of students.

\section{Acknowledgements}

The study was conducted as part of the DS-235 statutory grant of the Jozef Pilsudski University of Physical Education in Warsaw.

\section{References}

Alizadeh, Z., Kordi, R., Rostami, M., Mansournia, M.A., Hosseinzadeh-Attar, S.M., Fallah, J. (2013). Comparison Between the Effects of Continuous and Intermittent Aerobic Exercise on Weight Loss and Body Fat Percentage in Overweight and Obese Women: A Randomized Controlled Trial. International Journal of Preventive Medicine, 4 (8), 881-888.

Barabasz, Z., Zadarko, E. (2010). Diagnoza stanu i perspektywa zmian w obrębie studenckiej kultury fizycznej. In: Z. Barabasz, E. Zadarko (eds), Aktywność przez całe życie. Zdrowie i sprawność studentów pod kontrolą (pp. 47-76). Krosno: PWSZ.

Brničević, M.M., Duplančić, D., Jukić, J. (2014). Differences in some morphological characteristics between students of faculty of economics and faculty of kinesiology in Split. Research in Physical Education, Sport and Health, 3 (2), 113-118. 
Carter, J.E.L. (2002). The Heath-Carter Anthropometric Somatotype-Instruction Manual. Revised. San Diego: San Diego State University.

Carter, J.E.L., Heath, B. (1990). Somatotyping. Development and applications. Cambridge: University Press.

Charzewska, J., Kopiczko, A., Bieńko, N., Pastuszak, A. (2017). Przewodnik do ćwiczeń z Antropologii. Część I. Zeszyt naukowo metodyczny. Warszawa: AWF.

Cynarski, W.J., Obodyński, K., Litwiniuk, A. (2005). The technical advancement and a level of chosen coordination motor abilities of people practicing karate. In: J. Sadowski (ed.), Coordination motor abilities in scientific research (pp. 428-433). Biała Podlaska: University School of Physical Education in Warsaw.

Czajkowska, A., Mazurek, K., Lutosławska, G., Żmijewski, P. (2010). Zależność pomiędzy dziennym wydatkiem energetycznym a wybranymi wskaźnikami somatycznymi i fizjologicznymi studentów AWF. In: K. Buśko, J. Charzewska, K. Kaczanowski (eds), Współczesne metody badań aktywności sprawności i wydolności fizycznej człowieka (pp. 58-69). Warszawa: AWF.

Ekblom, B., Engström, L.M., Ekblom, O. (2007). Secular trends of physical fitness in Swedish adults. Scandinavian Journal of Medicine \& Science in Sports, 3, 267-273.

Ekelund, U., Brage, S., Franks, P.W., Hennings, S., Emms, S., Wareham, N.J. (2005). Physical activity energy expenditure predicts changes in body composition in middle-aged healthy whites: effect modification by age. American Journal of Clinical Nutrition, 81 (5), 964-9.

Hickner, R.C., Mehta, P.M., Dyck, D., Devita, P., Houmard, J.A., Koves, T., Byord, P. (2001). Relationship between fat-to-fat-free mass ratio and decrements in leg strength after downhill running. Journal of Applied Physiology, 90, 1334-1341.

Huang, T.T., Harris, K.J., Lee, R.E., Nazir, N., Born, W., Kaur, H. (2003). Assessing overweight, obesity, diet and physical activity in college students. Journal of American College Health, 52 (2), 83-86.

Kaźmierczak, A., Bolesławska, I., Główka, A., Dzięcioł, M., Przysławski, J. (2012). Ocena wybranych parametrów antropometrycznych wśród młodzieży akademickiej Poznania. Bromatologi i Chemia Toksykologiczna, 45 (3), 1099-1104.

Khasawneh, A. (2015). Prevailing somatotypes and their contribution to motor coordination abilities among the students of the physical education college. Advances in Physical Education, 05 (03), 176-187.

Kromhout, D., Bloemberg, B., Seidell, J.C., Nissinen, A., Menotti, A. (2001). Physical activity and dietary fiber determine population body fat levels: the Seven Countries Study. International Journal of Obesity and Related Metabolic Disorders, 25 (3), 301-6.

Maaroos, J., Landor, A. (2001). Anthropometric indices and physical fitness in university undergraduates with different physical activity. Anthropologischer Anzeiger, 59 (2), 157-163.

Milicer, H., Skibińska, A., Skład, M. (1974). Trend sekularny wielkości i proporcji ciała młodzieży akademickiej. Wychowowanie Fizyczne i Sport, 18 (4), 63-71.

Mirek, W., Mleczko, E. (2005). Ocena znaczenia głównych czynników środowiskowych w kształtowaniu podstawowego komponentu sprawności $\left(\mathrm{VO}_{2}\right.$ max) w ramach koncepcji Health-Related Fitness. Annales Universitatis Mariae Curie-Skłodowska. Vol. LX. SUPPL. XVI. 323 Sectio D.

Mleczko, E., Januszewski, J. (2009). Long-term trends of changes in physical and motor development observed among Cracovian students. Kinesiology, 46, 65-79.

Nikbakht, M. (2011). Relationships between somatotype, anthropometry and physical fitness variables in untrained university students. Journal of Physical Education and Sport, 11 (2), 211-214.

Pasiut, U. (2012). Stan biologiczny studentów i studentek akademii wychowania fizycznego na tle ogółu młodych osób dorosłych studiujących w największych państwowych uczelniach Krakowa. Antropomotoryka, 60, 111-122.

Peterson, J., Koskel, S. (2006). Relations between body build and foodstuffs consumption in female students (aged 17-23 years) of the University of Tartu. Papers on Anthropology, 15, 150-177.

Phaswana, M., Ramalivhana, F.W., Amusa, L.O. (2015). Body composition and cardiorespiratory endurance profiles of students at the Centre for Biokinetics, Recreation and Sport Science, University of Venda, South Africa. African Journal for Physical, Health Education, Recreation and Dance, 2, 401-413.

Raschka, C., Aichele, S.K. (2014). Correlations between somatotypes and nutritional intake in sports students. Papers on Anthropology, $23(2), 96-104$.

Saczuk, J., Wasiluk, A., Wilczewski, R., Wilczewski, A. (2016). Differences in body build and physical fitness of PE students from the faculty of physical education and sport in Biała Podlaska in the years 1989, 2004, and 2014. Polish Journal of Sport and Tourism, $23(4), 212-215$ 
Saha, S. (2015). Morphological Characteristics and Explosive Power of Athlete and Non-Athlete. Arch Exerc Health Dis, 5 (1-2), 354-358. DOI: 10.5628/aehd.v5i1-2.174.

Saritas, N., Özkarafaki, I., Pepe, O., Büyükipekçi, S., Çoksevim, B. (2010). The investigation somatotype profiles of university students. Ovidius University Annals, Series Physical Education and Sport /Science, Movement and Health, 10 (2), 288-294.

Stachoń, A., Burdukiewicz, A., Pietraszewska, J., Andrzejewska, J. (2012). Changes in body build of AWF students 1967-2008. Can a secular trend be observed? Human Movement, 2, 109-119.

Stachoń, A., Pietraszewska, J., Burdukiewicz, A., Andrzejewska, J. (2013). Wpływ aktywności fizycznej na poziom otłuszczenia młodych kobiet. Medycyna Ogólna i Nauki o Zdrowiu, 19 (2), 188-192.

Teixeira, P.J., Sardinha, L.B., Going, S.B., Lohman, T.G. (2001). Total and regional fat and serum cardiovascular disease risk factors in lean and obese children and adolescents. Obesity Research, 9 (8), 432-42.

Tjønna, A.E., Lee, S.J., Rognmo, Ø.R., Stølen, T.O., Bye, A., Haram, PM., Loennechen, J.P., Al-Share, Q,Y., Skogvoll, E., Slørdahl, S.A., Kemi, O.J., Najjar, S.M., Wisløff, U. (2008). Aerobic Interval Training Versus Continuous Moderate Exercise as a Treatment for the Metabolic Syndrome: A Pilot Study. Circulation, 118 (4), 346-354.

Truter, L., Pienaar, A.V., DuToit, D. (2010). Relationships between overweight, obesity and physical fitness of nine- to twelve-year-old South African children. South African Family Practice, 52 (3), 227-233.

Tzarova, R. (2013). Somatotypes particularities of the high students from profiled groups in swimming. Activities in Physical Education and Sport, 3 (1), 4-7.

Vedat, A. (2013). Somatotypes of Male Whitewater Canoe Athletes of the Turkish National Canoe Team. African Journal of Agricultural Education, 1 (3), 051-055.

Weiner, J.S., Lourie, J.A. (1969). Human Biology, A guide to Field Methods, IBP Handbook no 9, Oxford and Edinburgh.

Yildiz, Y., Karakaş, S., Güneş, H., Köse, H. (2009). Reflection of sport awareness on body composition in students at the School of Physical Education and Sports. Medical Journal of Trakya University, 26 (3), 249-255.

Cite this article aS: Gryko, K., Kopiczko, A., Krawczyk, K., Maliszewska, I., Perkowski, K. (2019). Somatic and Typological Differentiation of First-year Male and Female Students from the Jozef Pilsudski University of Physical Education in Warsaw. Central European Journal of Sport Sciences and Medicine, 4 (28), 5-14. DOI: 10.18276/cej.2019.4-01. 